\title{
Different Ground Corn Particle Size in Supplements for Young Bulls Grazing During Intensive System Production
}

Lucien Bissi da Freiria ( $\sim$ lucien.freiria@ifro.edu.br)

Instituto Federal de Rondonia: Instituto Federal de Educacao Ciencia e Tecnologia de Rondonia https://orcid.org/0000-0003-3715-5228

Joanis Tilemahos Zervoudakis

Universidade Federal de Mato Grosso

Nelcino Francisco de Paula

Universidade Federal de Mato Grosso

Mozart Alves Fonseca

University of Nevada Reno

Luciana Keiko Hatamoto-Zervoudakis

Universidade Federal de Mato Grosso

Pedro Ivo José Lopes da Rosa e Silva

Universidade Federal de Mato Grosso

Yasmim Rodrigues Vilas Boas e Silva

Universidade Federal de Mato Grosso

Adriano Jorge Possamai

Cargill Animal Nutrition

\section{Research Article}

Keywords: digestibility, fecal concentration, intake, grinding

Posted Date: June 10th, 2021

DOl: https://doi.org/10.21203/rs.3.rs-544388/v1

License: (c) (1) This work is licensed under a Creative Commons Attribution 4.0 International License.

Read Full License 


\section{Abstract}

We hypothesized that a decrease in flint corn particle size in the supplements of young bulls during grazing promotes better use of starch in the total gastrointestinal tract, with less starch lost in the feces, thus increasing growth performance. This experiment aimed to evaluate the effects of supplements with different ground corn particle sizes on the growth performance, economic analysis, intake and apparent digestibility of nutrients for beef cattle in Urochloa brizantha cv. Marandu pastures during the rainy-dry transition season. Sixty-four Nelore bulls, with an average age of 16 months and $303.6 \pm 18.0 \mathrm{~kg}$ of body weight (BW), were distributed in a completely randomized design. The treatments were $W G=$ whole grain (geometric mean particle size, $\left.d_{g w}, 6.262 \mu \mathrm{m}\right) ; C G=$ coarse ground grain $\left(d_{g w}, 2.882 \mu \mathrm{m}\right) ; M G=$ medium ground grain $\left(\mathrm{d}_{\mathrm{gw}}, 1.011 \mu \mathrm{m}\right)$; and $\mathrm{FG}=$ fine ground grain $\left(\mathrm{d}_{\mathrm{gw}}, 0.621 \mu \mathrm{m}\right)$. The supplements with ground grain or whole grain were similar $(P>0.05)$ in terms of intake and the digestibility of dry matter (DM), forage, organic matter $(\mathrm{OM})$, crude protein $(\mathrm{CP})$, neutral detergent fiber corrected for ash and protein (NDFap), and total digestible nutrients (TDN). However, the starch digestion in the total tract was higher $(P<0.05)$ with ground grain than with whole grain. The different geometric mean particle sizes of the grain in the supplements were not sufficient to alter $(P>0.05)$ the starch digestion in the total tract. The starch fecal concentration decreased with ground grain compared with that for whole grain $(P<0.05)$. However, no differences in growth performance were observed among the treatments $(P>0.05)$. Supplementation with CG promoted a slightly greater net revenue $(+11.51 \%)$ and return per ha $(+12.8 \%)$ compared with WG, while MG and FG yielded worse economic results. Therefore, CG showed higher economic performance and efficiency utilization of starch, suggesting it is a better strategy for providing supplements to young grazing bulls.

\section{Introduction}

Currently, reducing the production cycle is an important way of intensifying beef production and for improving meat quality. In this sense, the growth phase requires attention since greater feed efficiency in this period can promote the slaughter of younger animals and provide areas for use by other animals (Euclides et al., 2001; Paulino et al., 2006). In the growth phase, the inclusion of a higher supplementation level $(10 \mathrm{~g} / \mathrm{kg} \mathrm{BC})$ for animals on pasture, mainly in tropical regions, is a good strategy and has the potential to improve performance because the livestock require nutrition to maximize production (Detmann et al., 2011; Fernandes et al., 2012).

In most of the diets for beef cattle, corn is used in high inclusions as an important starch source for ruminants (Owens et al., 1986; 1997; Zinn et al., 2011). Strategies for improving available starch in the gastrointestinal tract, with techniques such as grain processing, have been extensively evaluated in feedlots (Huntington, 1997; Owens et al., 1997; Zinn et al., 2002, 2007). However, most of these studies evaluated dent corn in feedlot diets (Owens and Soderlund, 2007); dent corn is less vitreous than flint corn, which is typically fed in Brazilian feedlots (Correa et al., 2002). The flint corn has a protein matrix surrounding the starch granules, with less starch available for microbial fermentation in the rumen 
(McAllister et al., 2006). Thus, processing (grinding) of flint corn grain would be expected to have a greater benefit than grinding dent corn (Gouvêa et al., 2016).

In the beef cattle production system at pasture, it is important to consider the possible effects of processing/grinding corn grain in supplements on forage intake. Initially, the particle reduction size of corn grain with grinding would increase the surface area for microbial attachment and colonization (McAllister et al., 2006), with a potential increase in energy available to improve animal performance. However, reducing the sizes of the grain particles may decrease chewing and rumination or increase the passage rate, impairing the rate and extension of fiber digestion (Kung et al., 1983). On the other hand, the use of a larger particle of corn grain (whole) can reduce starch digestibility in the gastrointestinal tract (Owens and Soderlund, 2007).

We evaluated flint corn grain with different degrees of grinding for use as supplements in terms of nutrient intake and digestibility, starch fecal concentration, growth performance and economics of Nellore bulls in the growth phase at pasture.

\section{Materials And Methods}

This trial was conducted at the Faculdade de Agronomia e Zootecnia, Universidade Federal de Mato Grosso (UFMT; Cuiabá, Mato Grosso, Brazil), following humane animal care and handling procedures, according to the UFMT guidelines (Protocol 23108.060964/13 - 6).

\section{Experimental design and treatments}

The experiment was conducted in the rainy-dry transition season at the beef cattle facility of the Sector Nutrition of Beef Cattle at Pasture, Universidade Federal de Mato Grosso - UFMT, from March 2016 to June 2016. The climate is classified as tropical (Aw in the Köppen international system), the average maximum temperature is $32.8^{\circ} \mathrm{C}$, and the average minimum temperature is $19.7^{\circ} \mathrm{C}$.

Sixty-four young bulls (Nelore) with an average age of 15 months and $305 \pm 17.81 \mathrm{~kg}$ of body weight (BW) were used in the experiment to evaluate the effects of varying the ground corn size in their supplements on intake and nutrient digestibility, performance and economics. The experiment was structured in a completely randomized design with 4 treatments. The experiment lasted 90 days, divided into 3 experimental periods of 30 days.

Initially, the animals were weighed, identified, treated against ecto- and endoparasites by administration of ivermectin (Ivomec; Merial, Paulínea, Brazil), and allocated into 16 paddocks of 0.81 ha each, with 4 young bulls randomly allocated to 1 of 4 treatments. The paddocks were seeded with Brachiaria brizantha cv. Marandu forage and were fitted with smooth wire fencing, waters, and feed bunks. The digestibility trial was conducted with one animal in each paddock between days 41 and 50 . To evaluate intake and nutrient digestibility, $7 \mathrm{~d}$ were allowed for adaptation to external indicators, and $3 \mathrm{~d}$ were allowed for fecal sampling. 
The effects of different ground corn sizes in the supplements were evaluated using the following treatments: 1-Whole grain (geometric mean particle size, $\left.d_{g w}, 6.262 \mu \mathrm{m}, W G\right) ; 2$-Coarse ground grain ( $d_{\text {gw }}$ $2.882 \mu \mathrm{m}, \mathrm{CG})$; 3-Medium ground grain ( $\left.\mathrm{d}_{\mathrm{gw}}, 1.011 \mu \mathrm{m}, \mathrm{MG}\right)$; and 4-Fine ground grain $\left(\mathrm{d}_{\mathrm{gw}}, 0.621 \mu \mathrm{m}, \mathrm{FG}\right)$ (Table 1). The corn size was determined according to the methodology proposed by Yu et al. (1998).

The supplement was provided at $10 \mathrm{~g} / \mathrm{kg} \mathrm{BW}$ daily at 10:00 am. The supplements were formulated to be isonitrogenous, with CP contents of approximately $22 \%$. The proportions of the ingredients and the chemical composition of the forage and supplements are showed in Table 1.

The average sward height was randomly measured by reading 100 sampling points in each paddock with a measuring stick graduating in centimeters (Barthram, 1985). The forage mass in each paddock was estimated for each period $(30 \mathrm{~d})$. Three forage samples were collected by clipping all forage within a 0.25 $\mathrm{m}^{2}$ frame in each paddock at each sampling to a $5.0 \mathrm{~cm}$ stubble height with hand shears, according to the average sward height. The clipped samples were dried to a constant weight under forced air at $55^{\circ} \mathrm{C}$ for $72 \mathrm{~h}$. The estimate forage mass and potentially digestible dry matter, according to Detmann et al. (2016), for multiplied by the paddock area by dry weights of these clippings.

The paddocks were managed through continuous stocking (Allen et al., 2011). Forage samples to address the herbage chemical composition were collected using a hand plucking methodology

(Johnson, 1978) to mimic forage selected by grazing bulls. Samples were collected from each pasture during each period and dried to a constant weight at $55^{\circ} \mathrm{C}$ under forced air, after, subsequent analysis of their chemical composition in to the laboratory.

Chemical composition analysis

Supplement ingredient samples, forage samples, and feces were dried at $55^{\circ} \mathrm{C}$ for $72 \mathrm{~h}$. Samples were then ground in a Wiley mill (Thomas Scientific, Swedesboro, NJ) to pass through a $2 \mathrm{~mm}$ screen for indigestible neutral detergent fiber (iNDF) analysis (Valente et al. 2011). A subportion of $20 \mathrm{~g}$ of each sample was ground to pass through a $1 \mathrm{~mm}$ screen for analyses of dry matter (DM), ash, crude protein (CP), and neutral detergent fiber (NDF). Samples of forage, supplement ingredient samples and feces were analyzed following the procedures described by Detmann et al. (2012) for DM (index INCT-CA G003/1), CP (index INCT-CA N-001/1), ash (index INCTCA M-001/1), neutral detergent fiber corrected for contaminant ash, and protein (NDFom(n); index INCT-CA F-002/1, INCT-CA M-002/1, and INCT-CA N004/1).

The pdDM was estimated using the second pasture sample collected in each period, as described previously, using the following equation (Detmann et al. 2016):

$\operatorname{pdDM}(\%$; dry matter basis $)=0,98 *(100-N D F)+($ NDF-iNDF $)$;

where 0.98 is the true digestibility coefficient of the intracellular content; NDF is the forage content of neutral detergent fiber corrected for the residual ash and nitrogen; and iNDF is the forage content of 
indigestible neutral detergent fiber.

Intake Estimation

Intake and nutrient digestibility were estimated just once during the period between the 41 st day and the 50th day on the bulls in each paddock ( 16 animals, 4 bulls for each treatment) using the marker method. Chromium oxide, titanium dioxide and indigestible NDF (iNDF) were used to estimate the excretion of fecal matter (as dry weight), supplement intake and forage intake, respectively.

Fecal samples were collected on $\mathrm{d} 48,49$, and 50 , directly from the rectum, at 16:00,12:00, and 08:00 $\mathrm{h}$ on the first, second, and third days of collection, respectively. The fecal samples were dried at $55^{\circ} \mathrm{C}$ for 72 $\mathrm{h}$ and proportionately composited throughout the day for each animal based on the fecal dry weights.

To estimate DM fecal excretion, $15 \mathrm{~g}$ of chromium oxide was provided for $9 \mathrm{~d}$ by esophageal infusion; the first $7 \mathrm{~d}$ were used to stabilize fecal excretion of the marker, and the last $3 \mathrm{~d}$ were used to collect the samples (Titgemeyer et al., 2001). Chromium was determined in the feces by atomic absorption spectrophotometry (model 2380 spectrophotometer; PerkinElmer, Bois d'Arcy, France) at a wavelength of $357.9 \mathrm{~nm}$ with an air/acetylene flame directly on the supernatant obtained by centrifugation $(5,000 \times \mathrm{g}$ for 15 min at room temperature; Michalet-Doreau and Doreau, 2001).

Fecal DM excretion was estimated based on the ratio between the amount of marker supplied and its concentration in the feces, according to the equation described by Smith and Reid (1955):

$\mathrm{FE}=\left(\mathrm{CrO}_{2}\right.$ provided $/ \mathrm{CrO}_{2}$ concentration feces $) \times 100$

in which $\mathrm{FE}=$ fecal excretion $(\mathrm{g} / \mathrm{d}), \mathrm{CrO}_{2}$ provided = amount of chromium oxide provided $(\mathrm{g} / \mathrm{d})$, and $\mathrm{CrO}_{2}$ concentration feces $=$ chromium concentration in the feces $(\mathrm{g} / \mathrm{kg})$.

Dry matter voluntary intake (DMI) was estimated by using iNDF as an internal marker (Valente et al. 2011) by the equation:

DMI $(\mathrm{kg} /$ day $)=\{[\mathrm{FE} \times$ fecal iNDF $)-$ supplement iNDF $] \div$ forage iNDF $\}+$ SDMI

in which fecal iNDF = iNDF in the feces (\%); supplement iNDF = iNDF in the supplement ( $\mathrm{kg} / \mathrm{day})$; forage $\mathrm{iNDF}=\mathrm{iNDF}$ in the forage $(\mathrm{kg} / \mathrm{kg})$ and SDMI = supplement dry matter intake $(\mathrm{kg} / \mathrm{day})$.

For the determination of individual consumption of the supplement (ICS), titanium dioxide was used at an average quantity of $20 \mathrm{~g} /$ animal and mixed with the supplement immediately before supplying it, according to the procedure described by Valadares Filho et al. (2006). For analysis, titanium dioxide content in the feces was determined according to the procedure described in Holleman and White (1989). The ICS was performed by following the same scheme of fecal collection as for chromium oxide, through the equation:

ICS $(\mathrm{g} /$ day $)=(\mathrm{FE} \times$ feces TiO $) \div$ supplement TiO 
where fecal TiO and supplemental TiO are the titanium dioxide concentrations in the feces and in the supplement, respectively.

For determination of iNDF, $0.5 \mathrm{~g}$ samples of feces, forage, and supplement were placed in 5 by $5 \mathrm{~cm}$ polypropylene bags (nonwoven fabric, weight $100 \mathrm{~g} / \mathrm{m}^{2}$ ). The samples were weighed to allow for $20 \mathrm{mg}$ $\mathrm{DM} / \mathrm{cm}^{2}$ of surface area (Nocek, 1988) and incubated in the rumen of a cannulated Nellore bull for a period of $288 \mathrm{~h}$ (Valente et al. 2011).

The fecal samples collected for the determination of DMI, ICS and forage intake in the digestibility trial were used $(50 \mathrm{mg}$ ) for the determination of starch excretion in the feces according to the methodology proposed by Hall (2009), and the supplemental sample was analyzed for the determination of starch intake.

Performance and Economic Analysis

After $14 \mathrm{~h}$ of solid fasting, young bulls were weighed at the beginning and end of the experiment for daily weight gain and total weight gain. The economic analysis was determined by the nutrition costs (supplementation and land occupation), operation, acquisition of the animals (US\$1.34/kg of BW), gross revenue, net profit, area production, and profitability during the feeding period.

The prices of the ingredients grain corn, soybean meal, mineral supplement and urea were $0.14,0.25,0.37$ and US $\$ .49 / \mathrm{kg}$, respectively. For the price of grinding corn based on the cost of the grinding machine with a 7 horse power motor, a price value of US\$ 673.85 , and consumption of $5.59 \mathrm{~kW} / \mathrm{h}$, flow rates for coarse ground corn $(2.882 \mu \mathrm{m})$, medium ground corn $(1.011 \mu \mathrm{m})$, and fine ground corn $(0.621 \mu \mathrm{m})$ of $1,300,1,000$ and $700 \mathrm{~kg} / \mathrm{h}$, respectively, were calculated. The price of power consumption, taking into account the mean year in Brazil, had a value of US\$ 0.25/kW.

Statistical Analysis

Nutrient intake and digestibility, fecal starch concentration, and performance data (initial weight; final weight, daily weight gain, total weight gain) were analyzed using SAS/STAT software (SAS Inst. Inc., Cary, $\mathrm{NC}$ ) as a randomized complete design with 4 treatments (4 corn grinding particle size). Only performance data considering the average of each paddock were considered 1 experimental unit, and another variable considered only each animal paddock. The model included the fixed effects of the ground corn particle size.

When no significant interactions $(P>0.05)$ were detected, the main effects of the ground corn particle size were examined. Differences between ground corn particle sizes were tested by an ANOVA F-test using orthogonal contrasts, where we compared: 1-WC vs GC (whole grain versus ground corn); 2-CG vs MG (coarse ground grain versus medium ground grain); and 3-CG vs FG (coarse ground grain versus fine ground corn). 


\section{Results}

We hypothesized that a decrease in flint corn particle size in the supplements of young bulls during grazing promotes a better use of starch in the total gastrointestinal tract, with less starch loss in the feces, increasing growth performance.

Mean forage masses of 4,473, 3,017, 1,415, 1,438 and 1,619 kg/ha were observed for dry matter mass, potentially digestible dry matter, green leaves, green stems and senescent stems, respectively

(Table 2).

For the ground corn particle sizes in the supplements of young bulls during grazing, there was no difference $(P>0.05)$ across the treatments for the intake of dry matter $(D M)$, forage, supplement, organic matter (OM), crude protein (CP), neutral detergent insoluble fiber corrected for contaminant ash or protein (NDFap), or indigestible neutral detergent insoluble fiber (iNDF) (Table 3).

Similarly, the corn particle size in the supplements of young bulls during grazing did not alter $(P>0.05)$ the intake of digestible organic matter (DOM), digestible NDFap (D NDFap), total digestible nutrients (TDN), or grams of CP/kilogram of digestible OM (CP:DOM) (Table 3).

However, grinding the corn in the supplements promoted higher starch digestibility $(P<0.05)$ when comparing whole grain with all ground corn (WG vs. GC), with less fecal starch content $(P<0.05)$

(Table 4). That variable showed that independent of the ground corn particle size, there was more efficient utilization of starch in the supplements for ground corn versus whole grain.

However, the use of ground corn for young bulls during grazing is not justified in relation to nutrient digestibility; because there was no difference $(P>0.05)$ in the nutrient digestibility of $D M, O M, C P, N D F a p$, or TDN between whole and ground corn (Table 5).

Supplements with different ground corn particle sizes showed higher efficiency of starch use after grinding, but the same tendency was not confirmed for performance characteristics because, in the actual trial, animals did not show differences in body weight $(\mathrm{kg})$, average daily gain $(\mathrm{kg} /$ day) or total gain $(\mathrm{kg})$ (Table 6).

Thus, applying the grinding process increased the costs for the animals by US\$ $0.00,0.28,0.37$ and 0.53 /period and the total costs by US $\$ 499.68,507.08,506.73$ and $504.95 /$ period for whole corn and coarse, medium and fine ground grain corn, respectively (Table 7).

However, supplements with coarse ground corn promoted higher kilograms produced per hectare (209.3 $\mathrm{kg}$ ), resulting in a higher economic return during the study period $(12.67 \%$ ) and a higher return per ha (US\$ $250.97 /$ ha/period) compared to the other supplements (Table 7). The supplement with whole grain showed results close to that of supplementation with coarse ground grain corn. Supplementation with 
fine ground grain corn showed inferior economic performance results compared with the other treatments.

\section{Discussion}

The dry matter of forage mass remained greater than the threshold indicated as limiting to animal selectivity, 4,262 kg/ha (Euclides et al., 1992) and 2,000 kg/ha (Minson, 1990). However, during the trial, in the rainy-dry transition season, a decrease in green leaves and an increase in the senescent part of the forage were observed due to the lower abundance of rain. This condition is marked by a reduction in the leaf:stem ratio, promoting increased thickness and lignification of the cell wall (Minson, 1990). The performance of animal grazing is associated with the quality and quantity of the forage mass. According to Paulino et al. (2008), the integrative measure of the quantity and quality aspects of forage is determined by the potentially digestible dry matter (pdDM) of the forage mass. It reveals the real ability to support animal performance in the area used. Therefore, Paulino et al. (2004) determined that supplying 40 and $50 \mathrm{~g} / \mathrm{kg} \mathrm{BW}$ pdDM of forage was necessary for satisfactory animal grazing performance. An average pdDM of mass forage of $73.67 \mathrm{~g} / \mathrm{kg}$ of BW was observed, which may be considered nonrestrictive in relation to animal performance. The pdDM corresponding to $67.44 \%$ of mass forage ( $\mathrm{kg}$ $\mathrm{DM} / \mathrm{ha})$, while

Barros et al. (2014) and Pesqueira-Silva et al. (2015), in the same season, found values of 62.92 and $69.02 \%$, respectively.

Normally, animals in grazing have forage intake higher than $15 \mathrm{~g} / \mathrm{kg}$ of BW in the dry season and are supplemented with mixture minerals only (Couto et al., 2010; Sales et al., 2011; Paula et al. 2011). In this experiment, the supplementation level $(10 \mathrm{~g} / \mathrm{kg} \mathrm{BW})$ resulted in a reduction in forage intake, but it was less than $10 \mathrm{~g} / \mathrm{kg}$ BW in all treatments. Supplementation likely replaces forage intake because, in the literature, when the supplementation level is less than $3 \mathrm{~g} / \mathrm{kg} \mathrm{BW}$, it could provide increased forage and total dry matter intake, and when the supplementation level is higher than $5 \mathrm{~g} / \mathrm{kg} \mathrm{BW}$, it could promote a reduction in forage intake and a maintained or reduced total dry matter intake (Paulino et al., 2005;

Porto et al., 2009; Assad et al. 2015).

Nevertheless, the higher supplementation level provides protein and energy for animals in conditions of lower mass volume, which could favor the animal replacing forage intake (which has less energy and a higher mass volume) with supplementation, being more metabolically comfortable for the animals, but does not always reduce their total dry matter intake (Detmann et al., 2010). Sales et al. (2008) showed that an increase in supplementation levels $(0,3.44,5.36$, and $6.28 \mathrm{~g} / \mathrm{kg}$ of BW) decreased forage intake but maintained the same dry matter intake for cattle during grazing (dry season). All animals were supplied the same supplementation level in the actual trial, with an average dry matter intake of 19.50 $\mathrm{g} / \mathrm{kg} \mathrm{BW}$ and a slightly greater value of $18.01 \mathrm{~g} / \mathrm{kg} \mathrm{BW}$ than that found by 
Sales et al. (2008) at a higher supplementation level $(6.28 \mathrm{~g} / \mathrm{kg} \mathrm{BW})$. This result is in agreement with Detmann et al. (2010); for animals that prefer a reduced mass intake, a lower volume and higher energy are provided by supplements.

Supplementation with ground corn of different particle sizes did not change the nutrient or forage intake of the animals in the pastures. A reduction in flint corn grain particle sizes and higher starch release in the rumen are expected to occur with increased fermentation (Cole et al., 1976;

Aschenbach et al., 2011; Gouvêa et al., 2016), reducing the ruminal pH, which is negatively implicated in microbial fermentation of fiber because cellulolytic bacteria are $\mathrm{pH}$ sensitive, and their growth is inhibited when their ruminal pH is below 6.0 (Russell and Wilson,1996). However, this experiment did not observe a change in forage intake with reduced corn particle size.

It is possible that grinding grain flint corn was not sufficient to release the starch while reducing ruminal pH. In accordance with Owens et al. $(1986,1997)$, the reported process of grinding corn did not efficiently rupture the protein matrix. Nevertheless, grinding flint corn promoted much better starch digestibility and a lower starch content in feces than whole grain. These results are in agreement with Schwandt et al. (2016), who found flint corn for cattle feedlot to have a decreased (dry-rolled) grain corn particle size, an increase of in situ starch disappearance after a $24 \mathrm{~h}$ incubation, and a decreased fecal starch content.

These results regarding total tract starch digestion, mainly during grazing, might be explained by the reduction of the particle size with grinding compared with whole corn, increasing the surface area available for microbial attachment and colonization (Philippeau et al., 1999; McAllister et al., 2006) and improving starch digestibility. Zinn et al. (2007) showed an equation $\left(r^{2}=0.96\right)$ for starch digestibility increases when a decrease in starch fecal content occurs. Additionally, among the types of grinding (coarse, medium and fine), there was no change in the total tract starch digestion or fecal starch concentrations; it is possible that grinding corn is not adequate for removal of the protein barrier around the starch granules.

Owens and Soderlund (2008) reported improved starch digestion in ruminal and postruminal environments, which could be attributed to more extensively processed grain (steam-flaked and high moisture). Turgeon et al. (1983) reported that starch digested postruminally was not influenced by corn particle size, suggesting that the improved total tract starch digestion was due to the extent of ruminal digestion.

On average, the treatments with ground corn resulted in $77 \%$ total tract starch digestion, 22 percentage points higher than whole grain starch digestion. That difference might occur because there was an increase in ruminal digestibility. In a review, Owens and Soderlund (2008) discussed that in feedlot cattle, starch digestion in the rumen and total tract is higher for dry-rolled corn than whole corn, but in the same comparison of processing, there was no observed difference in starch digestion in the small or large intestine, which showed differences for corn particle size and higher ruminal digestibility only. 
However, in terms of the entire digestive tract for starch digestion with ground or whole grain, the difference indicates there was a higher pass rate of starch by another compartment in the digestive tract. Zinn et al. (2002) affirmed that more starch in the large intestine may reduce its $\mathrm{pH}$, impairing the growth of microorganisms that digest fiber. However, hypostases were not confirmed here because the use of ground corn of different particle sizes or whole corn in the supplements did not promote differences in nutrient digestibility, including fiber digestion.

Nevertheless, the literature indicates there is higher starch digestion in the small intestine, which is more energy efficient. There are minor losses due to methane and calories for digestion in the rumen, but glucose absorbed in the small intestine is directed for accumulation in the visceral fat, not in the tissue as intramuscular or subcutaneous fat, so it has less economic value (McLoad et al., 2007).

Thus, in any study with supplementation levels above $5 \mathrm{~g} / \mathrm{kg} \mathrm{BW}$ for cattle during grazing in the dry season, NDF digestibility was maintained at 50-60\% (Porto et al. 2011; Sales et al., 2008), which was slightly greater than the actual value. This might suggest two affirmations: first, that particle size reduction of corn does not influence NDF digestibility, and second, higher-level inclusion of supplements for animals during grazing reduces their dependency on the forage mass for nutrient digestibility.

The performance of animals in pastures was not influenced by the different levels of grinding of corn in the supplements. In feedlots, Schwandt et al. (2016) also did not find a difference in the performance of animals fed dry-rolled corn grain coarse, medium or fine. Perhaps higher starch availability demonstrated an increase in starch digestibility and a decrease in starch fecal concentration, which may not be enough to improve performance because there is no difference in total digestible nutrient (TDN) intake.

According to Valadares Filho et al. (2016), for a performance of $1 \mathrm{~kg} /$ day for animals during grazing, the growth phase requires an intake of $4.89 \mathrm{~kg}$ TDN/day. There was no difference among the treatments in terms of TDN intake, with a medium value of $5.01 \mathrm{~kg} /$ day, which may explain the slightly higher gain than expected.

In general, the economic analysis showed that grinding the corn created an increased period cost compared to that of supplying whole corn by $6.12,6.51$ and $7.11 \%$. According to Gorocica-Buenfil and Loerch (2005), conflicting reports have been published on the benefits of grinding corn, and the lack of response in diet digestibility and beef cattle feedlot performance to corn grinding suggests that the additional cost of grinding corn may not be justified. In this experiment, as it did not affect nutrient intake or digestibility, the same finding as in feedlots, grinding may not be justified.

However, even with the cost of grinding, when coarse ground grain was supplied, a slightly greater net revenue $(+11.51 \%)$ and return per ha $(+12.8 \%)$ were observed compared with whole grain, which occurred due to numerical differences in performance, which implicate reduce in total cost for kg produced. However, medium ground grain and fine ground grain had worse economic results than coarse ground grain. 
Therefore, grinding corn improves the efficient utilization of starch in the total tract compared with whole corn but was not enough to increase growth performance. Thus, using economic analysis is determinant in defining coarse ground grain corn as a better strategy in supplementing beef cattle during grazing.

\section{Conclusion}

The coarse grinding of corn in the supplement improved the efficient utilization of starch with less starch in the feces. Thus, coarse ground corn has a higher economic performance and is a better strategy for supplementing young bulls during grazing.

\section{Declarations}

\section{Author's contributions}

LF, JZ, PS, and YS conceived and designed research. LF, PS, and YS conducted experiments. JZ and NP contributed new reagents or analytical tools. LF, JZ, MF and NP analyzed data. LF, JZ, NP, MF, LZ and AP wrote the manuscript. All authors read and approved the manuscript.

\section{Acknowledgments}

We appreciate CAPES (Coordenação de Aperfeiçoamento de Pessoal de Nível Superior and UFMT (Universidade Federal de Mato Grosso).

\section{Funding}

information is not applicable / No funding was received.

\section{Conflicts of interest/Competing interests}

The authors declare no conflict of interest

\section{Availability of data and material}

the trial is the availability of data and material

\section{Code availability}

Not applicable 


\section{Ethics approval}

\section{The trial was performed at the Faculdade de Agronomia e Zootecnia, Universidade Federal de Mato Grosso (UFMT; Cuiabá, Mato Grosso, Brazil), and it followed humane animal care and handling procedures based on UFMT guidelines (Protocol 23108.060964/13-6).}

\section{Consent to participate}

All authors consented to participate in the study.

\section{Consent for publication}

All authors consented to the publication of the study.

\section{References}

1. Allen, V.G., Batello, C., Berretta, E. J., Hodgson, J., Kothmann, M., Li, X., Mclvor, J., Milne, J., Morris, C., Peeters, A., and Sanderson, M. 2011. An international terminology for grazing lands and grazing animals, Grass and Forage Science, 66,1, 2-28.

2. Aschenbach, J.R., Penner, G.B., Stumpff, F., Gäbel, G. 2011. RUMINANT NUTRITION SYMPOSIUM: Role of fermentation acid absorption in the regulation of ruminal $\mathrm{pH}$, Journal of Animal Science, 89, 1092-1107.

3. Assad, L.V.F., Zervoudakis, J.T., Cabral, L. Da S., Hatamoto-Zervoudakis, L.K., Paulino, P.V.R., Moraes, E.H.B.K., Silva-Marques, R.P. Da, Koscheck, J.F.W. 2015. Proteína degradável no rúmen e frequência de suplementação para novilhos Nelore em pastejo: Desempenho produtivo e análise econômica, Semina: Ciências Agrárias, 36, 3, 2105-2118.

4. Barros, L.V., Paulino, M.F., Moraes, E.H.B.K., Detmann, E., Almeida, D.M., Martins, L.S., Silva, A.G., Lopes, S.A., Márquez, D.E.C., Cardenas, J.E.G. 2014. Desempenho produtivo e nutricional de novilhas de corte em pastejo suplementadas no período da seca e/ou no período de transição seca-águas. Semina, 35, 4, 2655-2672.

5. Barthram, G.T. 1985. Experimental techniques: The HFRO sward stick. In: The Hill Farming Research Organization biennial report 1984/1985, Hill Farming Research Organization, Penicuik, Scotland, 2930.

6. Cole, N.A., Johnson, R.R., Owens, F.N., Males, J.R. 1976. Influence of roughage level and corn processing method on microbial protein synthesis by beef steers, Journal of Animal Science, 43, 497. 
7. Correa, C.E.S., Shaver, R.D., Pereira, M.N., Lauer, J.G., Kohn, K.. 2002. Relationship between corn vitreousness and ruminal in situ starch degradability, Journal of Dairy Science, 85, 3008-3012.

8. Couto, V.R.M., Paulino, M.F., Detmann, E., Valadares Filho, S.C., Sales, M.F.L., Barros, L.V., Porto, M.O., Valente, E.E.L. 2010. Energy sources and supplementation levels for beef heifers raised during the dry season. Revista Brasileira de Zootecnia, 39, 11, 2494-2501.

9. Detmann, E., Gionbelli, M.P., Paulino, M.F., Valadares Filho, S.C., Rennó, L.N., 2016. Considerations on research methods applied to ruminants under grazing, Nutritime Revista Eletrônica, 13, 4711-4731.

10. Detmann, E., Queiroz, A.C.de, Zorzi, K., Mantovani, H.C., Bayão, G.F.V., Gomes, M.P.C. 2011. Degradação in vitro da fibra em detergente neutro de forragem tropical de baixa qualidade em função da suplementação com proteína verdadeira e/ou nitrogênio não-proteico, Revista Brasileira de Zootecnia, 40, 6, 1272-1279.

11. Detmann, E., Souza, M.A., Valadares Filho, S.C., Queiroz, A.C., Berchielli, T.T., Saliba, E.O.S., Cabral, L.S., Pina, D.S., Ladeira, M.M., Azevedo, J.A.G., 2012. Métodos para análise de alimentos - INCT Ciência Animal, (Suprema Gráfica: Visconde do Rio Branco).

12. Detmann, E.; Paulino, M.F.; Valadares Filho, S.C. 2010. Otimização do uso de recursos forrageiros basais. In: SIMPÓSIO DE PRODUÇÃO DE GADO DE CORTE, 7, 2010, Viçosa, MG. Anais... Viçosa, MG: DZO-UFV, 2010. p.191-240.

13. Euclides, V.P.B., Euclides Filho, K., Costa, F.P., Figueiredo, G.R. de. 2001. Desempenho de novilhos F1s Angus-Nelore em pastagens de Brachiaria decumbens Submetidos a Diferentes Regimes Alimentares, Revista Brasileira de Zootecnia, 30, 2, 470-481.

14. Euclides, V.P.B., Macedo, M.C., Oliveira, M.P. 1992. Avaliação de diferentes métodos de amostragem (para estimar o valor nutritivo da forragem) sob pastejo. Revista Brasileira de Zootecnia, 21, 2, 691702.

15. Fernandes, H.J., Paulino, M.F., Detmann, E., Valadares Filho, S.DeC., Silva, A.G.da, Porto, M.O., Rocha, A.A.da, Biancardi, G.F. 2012. Avaliação nutricional, durante a amamentação, de tourinhos em pastejo recebendo suplementação proteica da amamentação à terminação, Revista Brasileira de Zootecnia, 41, 2, 374-383.

16. Gorocica-Buenfil, M.A., Loerch, S.C. 2005. Effect of cattle age, forage level, and corn processing on diet digestibility and feedlot performance, Journal of Animal Science, 83, 705-714.

17. Gouvêa, V.N., Batistel, F., Souza, J., Chagas, L.J., Sitta, C., Campanili, P.R.B., Galvani, D.B., Pires, A.V., Owens, F.N., Santos, F.A.P. 2016. Flint corn grain processing and citrus pulp level in finishing diets for feedlot cattle, Journal of Animal Science, 94, 665-677.

18. Hall, M.B. 2009. Determination of starch, including maltooligosaccharides, in animal feeds:

comparison of methods and a method recommended for AOAC collaborative study, Journal of AOAC International, 92, 1, 42-49.

19. Holleman DF, White RG.1989. Determination of digesta fill and passage rate from non-absorbed particulate phase markers using the single dose method. Canadian Journal of Zoology, 67, 488-494. 
20. Huntington, G.B. 1997. Starch utilization by ruminants: From basics to the bunk, Journal of Animal Science, 75, 852-867.

21. Johnson, A.D. 1978. Sample preparation and chemical analysis of vegetation. In: L. T. Manejte, editor, Measurement of grassland vegetation and animal production. Commonweath Agricultural Bureax, Aberustwysth, UK, 96-102.

22. Kung, L., Jr., Jesse, B.W., Thomas, J.W., Huber, J.T., Emery, R. S. 1983. High moisture ground ear corn, high moisture barley or sodium hydroxide treated barley for lactating cows: Milk production and ration utilization, Canadian Journal of Animal Science, 63, 155-162.

23. Leng, R.A. 1990. Factors affecting the utilization of "poor-quality" forages by ruminants particularly under tropical conditions, Nutrition Research Review, 3, 3, 277-303.

24. McAllister, T.A., Gibb, D.J., Beauchemin, K.A., Wang, Y. 2006. Starch type, structure and ruminal digestion. In: Proc. Cattle Grain Process. Symp., Tulsa, Oklahoma. http:// beefextension.com/proceedings/cattle_grains06/06-5.pdf. (Accessed 15 May 2017), 30-41.

25. McLeod, K.R., Baldwin, R.L., Harmon, D.L., Richards, C.J., Rumpler, W.V. 2001. Influence of ruminal and post ruminal starch infusion on energy balance in growing steers, in Energy Metabolism of Farm Animals. EAAP Publ. No. 103. Wageningen Pers, Wageningen, the Netherlands, 385- 388.

26. McLeod, K.R., Baldwin, R.L., Solomon, M.B., Baumann, R.G. 2007. Influence of ruminal and post ruminal carbohydrate infusion on visceral organ mass and adipose tissue accretion in growing beef steers, Journal of Animal Science, 85, 2256-2270.

27. Michalet-Doreau, B., Doreau, M.. 2001. Influence of drastic underfeeding on ruminal digestion in sheep, Animal Research, 50, 6, 451-462.

28. Minson, D.J. Forage in ruminant nutrition. San Diego: Academic Press, 1990. 483p.

29. Nocek, J.E. 1988. In situ and other methods to estimate ruminal protein and energy digestibility: A review, Journal of Dairy Science, 71, 8, 2051-2069.

30. Owens, F.N., Secrist, D.S., Hill, W.J., Gill, D.R. 1997. The effect of grain source and grain processing on performance of feedlot cattle: a review, Journal of Animal Science, 75, 868-879.

31. Owens, F.N., Soderlund, S. 2007. Ruminal And Postruminal Starch Digestion By Cattle. In: Proc. Cattle Grain Process. Symp., Tulsa, Oklahoma. http:// http://beefextension.com/proceedings/cattle_grains06/06-17.pdf. (Accessed 15 May 2017), 30-41.

32. Owens, F.N., Zinn, R.A., Kim, Y.K. 1986. Limits to starch digestion in the ruminant small intestine, Journal of Animal Science, 63, 1634-1648.

33. Paula, N.F., Zervoudakis, J.T., Cabral, L.S., Carvalho, D.M.G., Paulino, M.F., Hatamoto-Zervoudakis, L.K., Oliveira, A.A., Koscheck, J.F.W. 2011. Suplementação infrequente e fontes proteicas para recria de bovinos em pastejo no período seco: parâmetros nutricionais. Revista Brasileira de Zootecnia, 40, 4, 882-891.

34. Paulino, M. F., Detmann, E., Valadares Filho, S. C. 2008. Bovinocultura funcional nos trópicos. In: SYMPOSIUM OF BEEF CATTLE PRODUCTION, 6., 2008, Viçosa. Proceedings... Viçosa: UFV, Departamento de Zootecnia, 275-305. 
35. Paulino, M. F., Figueiredo, D. M., Moraes, E. H. B. K., Porto, M. O., Sales, M. F. S., Acedo, T. S., Villela, S. D. J., Valadares Filho, S. C. 2004. Suplementação de bovinos em pastagens: uma visão sistêmica. In: SYMPOSIUM OF BEEF CATTLE PRODUCTION, 4., 2004, Viçosa. Proceedings... Viçosa: UFV, Departamento de Zootecnia, 93-139.

36. Paulino, M.F., Detmann, E., Valadares Filho, S.De.C., Lana, R.De.P. 2002. Soja grão e caroço de algodão em suplementos múltiplos para terminação de bovinos mestiços em pastejo, Revista Brasileira de Zootecnia, 31, 1, 484-491.

37. Paulino, M.F., Moraes, E.H.B.K. de, Zervoudakis, J.T., Alexandrino, E., Figueiredo, D.M.De. 2005. Fontes de Energia em Suplementos Múltiplos de Auto-Regulação de Consumo na Recria de Novilhos Mestiços em Pastagens de Brachiaria decumbens durante o Período das Águas, Revista Brasileira de Zootecnia, 34, 3, 957-962.

38. Paulino, M.F., Moraes, E.H.B.K.De, Zervoudakis, J.T., Alexandrino, E., Figueiredo, D.M.De. 2006.

Terminação de novilhos mestiços leiteiros sob pastejo, no período das águas, recebendo suplementação com soja, Revista Brasileira de Zootecnia, 35, 1, 154-158.

39. Pesqueira-Silva, L.C.R., Zervoudakis, J.T., Cabral, L.S., Hatamoto-Zervoudais, L.K., Silva-Marques, R.P., Koscheck, J.F.W., Oliveira, A.A. 2015. Desempenho produtivo e econômico de novilhas Nelore suplementadas no período de transição seca-águas. Semina, 36, 3, 2235-2246.

40. Philippeau, C., Martin, C., Michalet-Doreau, B. 1999. Influence of grain source on ruminal characteristics and rate, site, and extent of digestion in beef steers, Journal of Animal Science, 77, 1587-1596.

41. Porto, M.O., Paulino, M.F., Detmann, E., Valadares Filho, S.C., Sales, M.F.L., Cavali, J., Nascimento, M.L., Acedo, T.S. 2011. Ofertas de suplementos múltiplos para tourinhos Nelore na fase de recria em pastagens durante o período da seca: desempenho produtivo e características nutricionais. Revista Brasileira de Zootecnia, 40, 11, 2548-2557.

42. Porto, M.O., Paulino, M.F., Valadares Filho, S.De.C., Sales, M.F.L., Leao, M.I., Couto, V.R.M. 2009. Fontes suplementares de proteína para novilhos mestiços em recria em pastagens de capimbraquiária no período das águas: desempenho produtivo e econômico, Revista Brasileira de Zootecnia, 38, 8, 1553-1560.

43. Russell, J. B., Wilson, D. B. 1996. Why are ruminal cellulolytic bacteria unable to digest cellulose at low pH? Journal of Dairy Science, 79, 1503-1509.

44. Sales, M.F.L., Paulino, M.F., Porto, M.O., Detmann, E., Valadares Filho, S.C., Acedo, T.S., Couto, V.R.M. 2008. Níveis de energia em suplementos múltiplos para terminação de novilhos em pastagem de capim-braquiária no período de transição águas-seca. Revista Brasileira de Zootecnia, 37, 4, 724733.

45. Sales, M.F.L., Paulino, M.F., Valadares Filho, S.C., Figueiredo, D.M., Porto, M.O., Detmann, E. 2011. Supplementation levels for growing beef cattle grazing in the dry-rainy transition season. Revista Brasileira de Zootecnia, 40, 4, 904-911. 
46. Schwandt, E.F., Wagner, J.J., Engle, T.E., Bartle, S.J., Thomson, D.U., Reinhardt, C.D. 2016. The effects of dry-rolled corn particle size on performance, carcass traits, and starch digestibility in feedlot finishing diets containing wet distiller's grains. Journal of Animal Science, 94, 1194-1202.

47. Smith, A.M., Reid, J.T. 1955. Use of chromic oxide as an indicator of fecal output for the purpose of determining the intake of pasture herbage by grazing cows, Journal of Dairy Science, 38, 5, 515-524.

48. Titgemeyer, E.C., Armendariz, C.K., Bindel, D.J., Greenwood, R.H., Löest, C.A. 2001. Evaluation of titanium dioxide as a digestibility marker for cattle, Journal of Animal Science, 79,1059-1063.

49. Turgeon, O.A., Jr., Brink, D.R., Britton, R. A. 1983. Corn particle size mixtures, roughage level, and starch utilization in finishing steer diets. Journal of Animal Science, 57, 739-749.

50. Valadares Filho, S.C., Moraes, E.H.B.K., Detmann, E. 2006. Perspectivas do uso de indicadores para estimar o consumo individual de bovinos alimentados em grupo. In: REUNIÃO ANUAL DA SOCIEDADE BRASILEIRA DE ZOOTECNIA, 43., João Pessoa. Anais... João Pessoa: SBZ, UFPB, 35:291-322.

51. Valente, T.N.P., Detmann, E., Queiroz, A.C., Valadares Filho, S.C., Gomes, D.I., Figueiras, J.F., 2011. Evaluation of ruminal degradation profiles of forages using bags made from different textiles, Revista Brasileira de Zootecnia, 40, 2565-2573.

52. Yu, P., Huber, J.T., Santos, F.A.P., Simas, J.M., Theurer, C.B. 1998. Effects of ground, steam-flaked, and steam-rolled corn grains on performance of lactating cows, Journal of Dairy Science, 81,777-783.

53. Zinn, R.A., Barreras, A., Corona, L., Owens, F.N., Plascencia, A. 2011. Comparative effects of processing methods on the feeding value of maize in feedlot cattle. Nutrition Research Reviews, 24, 183-190.

54. Zinn, R.A., Barreras, A., Corona, L., Owens, F.N., Ware, R.A. 2007. Starch digestion by feedlot cattle: Predictions from analysis of feed and fecal starch and nitrogen, Journal of Animal Science, 85, 1727-1730.

55. Zinn, R.A., Owens, F.N., Ware, R.A. 2002. Flaking corn: processing mechanics, quality standards, and impacts on energy availability and performance of feedlot cattle, Journal of Animal Science, $80,1145-1156$.

\section{Tables}


Table 1

Experimental supplement and chemical composition of the supplements and pasture $(\mathrm{g} / \mathrm{kg}$ on a DM basis)

\begin{tabular}{|c|c|c|c|c|}
\hline Item & & & & $\begin{array}{l}\text { Supplement } \\
\text { ( } \mathrm{g} / \mathrm{kg} \text { of } \mathrm{DM})\end{array}$ \\
\hline \multicolumn{5}{|l|}{ Ingredient } \\
\hline \multicolumn{4}{|l|}{ Corn grain ${ }^{1}$} & 715.7 \\
\hline \multicolumn{4}{|l|}{ Soybean meal } & 242.8 \\
\hline \multicolumn{4}{|l|}{ Urea:ammonium sulfate $(9: 1)$} & 20.9 \\
\hline \multicolumn{4}{|l|}{ Mineral supplement ${ }^{2}$} & 20.3 \\
\hline \multicolumn{5}{|c|}{ Chemical composition } \\
\hline \multirow[t]{2}{*}{ Item ${ }^{3}$} & \multirow[t]{2}{*}{ Supplement } & \multicolumn{3}{|c|}{ B. brizantha cv Marandu (hand plucking) } \\
\hline & & March/April & April/May & May/June \\
\hline DM & 910.5 & 916.4 & 912.4 & 903.5 \\
\hline $\mathrm{OM}$ & 951.5 & 912.4 & 919.7 & 911.5 \\
\hline $\mathrm{CP}$ & 220.5 & 90.5 & 84.1 & 91.5 \\
\hline NDIN (\% of total N) & - & 54.48 & 68.44 & 66.33 \\
\hline NDFap & 81.5 & 634.8 & 626.9 & 607.5 \\
\hline iNDF & - & 217.3 & 235.1 & 227.3 \\
\hline
\end{tabular}

${ }^{1}$ Corn grain treatment: WHOLE = whole corn $(6.262 \mu \mathrm{m})$; COARSE = coarse ground corn $(2.882 \mu \mathrm{m})$; MEDIUM = medium ground corn $(1.011 \mu \mathrm{m}) ; \mathrm{FINE}=$ fine ground corn $(0.621 \mu \mathrm{m})$

2 Mineral mixture: $198 \mathrm{~g}$ calcium; $60 \mathrm{~g}$ phosphorus; $117 \mathrm{~g}$ sodium; $5.1 \mathrm{~g}$ magnesium; $12.6 \mathrm{~g}$ sulfur; 17.7 mg iodine; 425 mg iron; 10,4 mg selenium; 80 mg cobalt; 527 mg manganese; 600 mg fluorine; $1000 \mathrm{mg}$ copper and $3000 \mathrm{mg}$ zinc.

${ }^{3} \mathrm{DM}$, dry matter, OM, organic matter; CP, crude protein; NDIN, neutral detergent insoluble nitrogen; NDFap, neutral detergent insoluble fiber corrected for contaminant ash, and protein; iNDF, indigestible neutral detergent insoluble fiber. 
Table 2

Forage mass and morphological components in the experimental periods

\begin{tabular}{|llllll|}
\hline Item $^{1}$ & Periods & & & SEM $^{2}$ & P value \\
\hline & March/April & April/May & May/June & \\
\hline DM (kg/ha) & $4,213.18$ & $4,913.41$ & $4,293.88$ & 201.39 & 0.06 \\
\hline pdDM (kg/ha) & $3,091.21$ & $3,222.57$ & $2,738.95$ & 157.39 & 0.09 \\
\hline Green leaf (kg/ha) & $1,883.59^{\mathrm{a}}$ & $1,331.11^{\mathrm{b}}$ & $1,031.28^{\mathrm{c}}$ & 119.97 & 0.01 \\
\hline Green leaf (\% DM) & $44.56^{\mathrm{a}}$ & $27.12^{\mathrm{b}}$ & $24.22^{\mathrm{b}}$ & 1.31 & 0.01 \\
\hline Green stem (kg/ha) & $1,183.90^{\mathrm{b}}$ & $1,874.53^{\mathrm{a}}$ & $1,258.34^{\mathrm{b}}$ & 126.05 & 0.01 \\
\hline Green stem (\% DM) & $28.09^{\mathrm{b}}$ & $38.17^{\mathrm{a}}$ & $28.92^{\mathrm{b}}$ & 1.20 & 0.01 \\
\hline Leaf: stem & $1.59^{\mathrm{a}}$ & $0.71^{\mathrm{b}}$ & $0.81^{\mathrm{b}}$ & 0.08 & 0.01 \\
\hline Senescent (kg/ha) & $1,145.67^{\mathrm{b}}$ & $1,707.76^{\mathrm{a}}$ & $2,004.24^{\mathrm{a}}$ & 141.30 & 0.01 \\
\hline Senescent (\% DM) & $27.34^{\mathrm{a}}$ & $34.70^{\mathrm{b}}$ & $46.85^{\mathrm{c}}$ & 1.66 & 0.01 \\
\hline
\end{tabular}

Means with the same letters in rows not differentiated with Tukey's test in probability $(P>0,05) .{ }^{1} \mathrm{DM}$ dry matter, pdDM (\%; dry matter basis) $=0,98 *(100-N D F)+\left(\right.$ NDF-iNDF). ${ }^{2}$ SEM standard error mean. 
Table 3

Dry matter and nutrient intakes according to the ground corn particle size in the supplementation of young bulls at pasture

\begin{tabular}{|lllllll|}
\hline Item $^{2}$ & \multicolumn{2}{l}{ Treatment $^{1}$} & & & SEM \\
\hline & WC & CG & MG & FG & & P Value \\
\hline & kg/day & & & & & \\
\hline DM & 6.88 & 7.21 & 7.31 & 7.14 & 0.394 & 0.88 \\
\hline Forage & 3.55 & 3.51 & 3.85 & 3.83 & 0.277 & 0.74 \\
\hline Supplement & 3.23 & 3.70 & 3.45 & 3.31 & 0.276 & 0.72 \\
\hline OM & 6.42 & 6.74 & 6.77 & 6.65 & 0.368 & 0.91 \\
\hline CP & 1.06 & 1.13 & 1.07 & 1.07 & 0.065 & 0.84 \\
\hline NDFap & 2.50 & 2.52 & 2.71 & 2.65 & 0.176 & 0.81 \\
\hline iNDF & 0.85 & 0.89 & 1.03 & 0.95 & 0.062 & 0.25 \\
\hline DOM & 3.96 & 3.69 & 3.70 & 4.10 & 0.309 & 0.73 \\
\hline DNDFap & 1.73 & 1.65 & 1.69 & 1.81 & 0.171 & 0.92 \\
\hline TDN & 5.01 & 5.05 & 4.91 & 5.09 & 0.307 & 0.98 \\
\hline CP:DOM & 0.274 & 0.308 & 0.292 & 0.261 & 0.014 & 0.15 \\
\hline & g/kg of BW (body & weight) & & & \\
\hline DM & 19.07 & 19.87 & 19.49 & 19.59 & 0.908 & 0.94 \\
\hline Forage & 9.87 & 9.71 & 10.28 & 10.53 & 0.806 & 0.88 \\
\hline Supplement & 9.19 & 10.15 & 9.21 & 9.05 & 0.547 & 0.49 \\
\hline OM & 17.80 & 18.60 & 18.05 & 18.22 & 0.840 & 0.92 \\
\hline NDFap & 6.95 & 6.95 & 7.22 & 7.26 & 0.502 & 0.95 \\
\hline iNDF & 2.37 & 2.46 & 2.75 & 2.61 & 0.174 & 0.46 \\
\hline
\end{tabular}

${ }^{1} \mathrm{WG}=$ whole grain $\left(\mathrm{d}_{\mathrm{gw}}, 6.262 \mu \mathrm{m}\right) ; \mathrm{CG}=$ coarse ground grain $\left(\mathrm{d}_{\mathrm{gw}}, 2.882 \mu \mathrm{m}\right) ; \mathrm{MG}=$ medium ground grain $\left(\mathrm{d}_{\mathrm{gw}}, 1.011 \mu \mathrm{m}\right) ; \mathrm{FG}=$ fine ground grain $\left(\mathrm{d}_{\mathrm{gw}}, 0.621 \mu \mathrm{m}\right)$.

2 DM, dry matter; OM, organic matter; CP, crude protein; NDFap neutral detergent insoluble fiber corrected for contaminant ash and protein; iNDF, indigestible neutral detergent insoluble fiber; DOM digestible organic matter, digestible NDFap, TDN, total digestible nutrients, CP:DOM grams of CP/kilogram of digestible OM. 
Table 4

The effects of ground corn particle size in supplements for young bulls during grazing: starch intake, starch digestibility and fecal starch

\begin{tabular}{|lccccccccc}
\hline Item $^{2}$ & \multicolumn{2}{c}{ Treatment $^{1}$} & \multicolumn{2}{c}{ SEM } & P value & Contrast $^{3}$ & & \\
\hline & WC & CG & MG & FG & & & $\begin{array}{l}\text { WC vs } \\
\text { GC }\end{array}$ & $\begin{array}{l}\text { CG vs } \\
\text { MG }\end{array}$ & $\begin{array}{l}\text { CG vs } \\
\text { FG }\end{array}$ \\
\hline $\begin{array}{l}\text { Intake, } \\
\text { kg }\end{array}$ & 1.43 & 1.59 & 1.48 & 1.42 & 0.11 & 0.72 & - & - & - \\
\hline Dig., g/g & 0.55 & 0.78 & 0.77 & 0.76 & 0.05 & 0.02 & $<0.01$ & 0.88 & 0.75 \\
\hline $\begin{array}{l}\text { Fecal, } \\
\text { g/g }\end{array}$ & 0.27 & 0.13 & 0.13 & 0.12 & 0.03 & 0.02 & $<0.01$ & 0.87 & 0.69 \\
\hline
\end{tabular}

${ }^{1} \mathrm{WG}=$ whole grain $\left(\mathrm{d}_{\mathrm{gw}}, 6.262 \mu \mathrm{m}\right) ; \mathrm{CG}=$ coarse ground grain $\left(\mathrm{d}_{\mathrm{gw}}, 2.882 \mu \mathrm{m}\right) ; \mathrm{MG}=$ medium ground grain $\left(\mathrm{d}_{\mathrm{gw}}, 1.011 \mu \mathrm{m}\right) ; \mathrm{FG}=$ fine ground grain $\left(\mathrm{d}_{\mathrm{gw}}, 0.621 \mu \mathrm{m}\right) .{ }^{2}$ Initial $\mathrm{W}$, initial weight; final $\mathrm{W}$, final weight; AGD, age weight daily; total WG, total weight gain. ${ }^{3}$ (WC vs GC, whole grain versus ground corn; CG vs MG coarse ground grain versus medium ground grain; $C G$ vs FG, coarse ground grain versus fine ground corn).

Table 5

A

Dry matter and nutrient digestibility according to the ground corn particle size in supplements for young bulls during grazing

\begin{tabular}{|c|c|c|c|c|c|c|}
\hline \multirow[t]{2}{*}{ Item ${ }^{2}$} & \multicolumn{3}{|c|}{ Treatment $^{1}$} & \multicolumn{2}{|c|}{ SEM } & \multirow[t]{2}{*}{$P$ value } \\
\hline & WC & CG & MG & FG & & \\
\hline & $\mathrm{g} / \mathrm{g}$ & & & & & \\
\hline DM & 0.550 & 0.591 & 0.586 & 0.595 & 0.017 & 0.37 \\
\hline $\mathrm{OM}$ & 0.572 & 0.612 & 0.611 & 0.618 & 0.018 & 0.41 \\
\hline $\mathrm{CP}$ & 0.606 & 0.641 & 0.625 & 0.613 & 0.016 & 0.15 \\
\hline NDFap & 0.635 & 0.672 & 0.633 & 0.648 & 0.0351 & 0.50 \\
\hline TDN & 0.701 & 0.704 & 0.715 & 0.713 & 0.011 & 0.26 \\
\hline
\end{tabular}

${ }^{1} \mathrm{WG}=$ whole grain $\left(\mathrm{d}_{\mathrm{gw}}, 6.262 \mu \mathrm{m}\right) ; \mathrm{CG}=$ coarse ground grain $\left(\mathrm{d}_{\mathrm{gw}}, 2.882 \mu \mathrm{m}\right) ; \mathrm{MG}=$ medium ground grain $\left(\mathrm{d}_{\mathrm{gw}}, 1.011 \mu \mathrm{m}\right) ; \mathrm{FG}=$ fine ground grain $\left(\mathrm{d}_{\mathrm{gw}}, 0.621 \mu \mathrm{m}\right) .{ }^{2} \mathrm{DM}$, dry matter; OM, organic matter; CP, crude protein; NDFap, neutral detergent insoluble fiber corrected for contaminant ash and protein. TDN, total digestible nutrients. ${ }^{3}$ (WC vs GC, whole grain versus ground corn; $C G$ vs MG coarse ground grain versus medium ground grain; $C G$ vs FG, coarse ground grain versus fine ground corn). 
Table 6

The effects of ground corn particle size in supplements of young bulls during grazing: animal performance

\begin{tabular}{|lllllll|}
\hline Item $^{2}$ & \multicolumn{2}{l}{ Treatment $^{1}$} & \multicolumn{3}{l|}{} \\
\hline & WC & CG & MG & FG & & \\
\hline initial W, kg & 303.0 & 304.6 & 304.1 & 302.5 & 0.89 & - \\
\hline final W, kg & 401.6 & 407.5 & 405.0 & 403.6 & 5.43 & 0.85 \\
\hline ADG, kg & 1.09 & 1.14 & 1.12 & 1.12 & 0.06 & 0.94 \\
\hline total WG, kg & 98.1 & 102.9 & 100.8 & 100.5 & 5.61 & 0.94 \\
\hline
\end{tabular}

${ }^{1} \mathrm{WG}=$ whole grain $\left(\mathrm{d}_{\mathrm{gw}}, 6.262 \mu \mathrm{m}\right) ; \mathrm{CG}=$ coarse ground grain $\left(\mathrm{d}_{\mathrm{gw}}, 2.882 \mu \mathrm{m}\right) ; \mathrm{MG}=$ medium ground grain $\left(\mathrm{d}_{\mathrm{gw}}, 1.011 \mu \mathrm{m}\right) ; \mathrm{FG}=$ fine ground grain $\left(\mathrm{d}_{\mathrm{gw}}, 0.621 \mu \mathrm{m}\right) .{ }^{2}$ Initial $\mathrm{W}$, initial weight; final $\mathrm{W}$, final weight; $A D G$, age daily gain; total $W G$, total weight gain. 
Table 7

The effects of ground corn particle size in supplements of young bulls during grazing: economic analysis

\begin{tabular}{|c|c|c|c|c|c|}
\hline \multirow[t]{2}{*}{ Item } & & \multicolumn{4}{|c|}{ Treatment $^{1}$} \\
\hline & & WC & CG & MG & FG \\
\hline Initial weight & $\mathrm{kg}$ & 303.00 & 304.60 & 304.10 & 302.50 \\
\hline Final weight & $\mathrm{kg}$ & 401.10 & 407.60 & 405.00 & 403.10 \\
\hline Period & day & 90 & 90 & 90 & 90 \\
\hline Production $\mathrm{kg}^{2}$ & Period/animal & 58.86 & 61.80 & 60.54 & 60.36 \\
\hline Production kg for ha & kg/Period/ha & 197.08 & 209.3 & 204.14 & 202.53 \\
\hline Stocking rate & $\mathrm{AU}^{3} / \mathrm{ha}$ & 3.89 & 3.91 & 3.89 & 3.87 \\
\hline \multicolumn{6}{|l|}{ Costs } \\
\hline Nutrition Cost ${ }^{4}$ & US\$/day/animal & 0.69 & 0.69 & 0.69 & 0.69 \\
\hline Operational Cost ${ }^{5}$ & US\$/day/animal & 0.30 & 0.30 & 0.30 & 0.30 \\
\hline Daily Cost ${ }^{6}$ & US\$/day/animal & 0.99 & 0.99 & 0.99 & 0.99 \\
\hline Total Nutrition Cost & US\$/Period/animal & 62.10 & 62.10 & 62.10 & 62.10 \\
\hline Total Operational Cost & US\$/Period/animal & 21.68 & 26.68 & 26.68 & 26.68 \\
\hline Grinding $^{7}$ & US\$/Period/animal & 0.00 & 0.28 & 0.37 & 0.53 \\
\hline Period Cost & US\$/Period/animal & 83.79 & 89.07 & 89.16 & 89.32 \\
\hline Weaning bulls buy ${ }^{8}$ & US\$/Period/animal & 408.36 & 410.51 & 409.84 & 407.68 \\
\hline Interest $^{9}$ & US\$/Period/animal & 7.46 & 7.49 & 7.48 & 7.46 \\
\hline Total Cost ${ }^{10}$ & US\$/Period/animal & 504.60 & 507.08 & 506.48 & 504.46 \\
\hline Nutritional Cost kg ${ }^{11}$ produced & US\$/kg & 1.06 & 1.00 & 1.03 & 1.03 \\
\hline Total Cost kg Produced ${ }^{12}$ & US\$/kg & 1.51 & 1.44 & 1.47 & 1.48 \\
\hline \multicolumn{6}{|l|}{ Economic Analysis } \\
\hline Gross Revenue $\mathrm{e}^{13}$ & US\$/animal & 562.19 & 571.30 & 567.65 & 564.99 \\
\hline Net Revenue ${ }^{14}$ & US\$/animal & 57.59 & 64.22 & 61.18 & 60.54 \\
\hline
\end{tabular}




\begin{tabular}{|llllll|}
\hline Item & \multicolumn{5}{c|}{ Treatment $^{1}$} \\
& \%/animal & 11.41 & 12.67 & 12.08 & 12.00 \\
\hline Profit $^{15}$ & \%/month/animal & 3.80 & 4.22 & 4.03 & 4.00 \\
\hline Profitability $^{16}$ & US\$/ha/Period & 222.49 & 250.97 & 238.02 & 234.38 \\
\hline Return for ha & & & & & \\
\hline
\end{tabular}

${ }^{1} \mathrm{WG}=$ whole grain $\left(\mathrm{d}_{\mathrm{gw}}, 6.262 \mu \mathrm{m}\right) ; \mathrm{CG}=$ coarse ground grain $\left(\mathrm{d}_{\mathrm{gw}}, 2.882 \mu \mathrm{m}\right) ; \mathrm{MG}=$ medium ground grain $\left(\mathrm{d}_{\mathrm{gw}}, 1.011 \mu \mathrm{m}\right) ; \mathrm{FG}=$ fine ground grain $\left(\mathrm{d}_{\mathrm{gw}}, 0.621 \mu \mathrm{m}\right) .{ }^{2}$ Production $\mathrm{kg}$ ((final weight - initial weight) ${ }^{\star} 0.60$ ), value of $60 \%$ is gain yield (estimated). ${ }^{3} \mathrm{AU}$ Animal Unit (body weight of $450 \mathrm{~kg}$ ). ${ }^{4}$ Nutrition cost is supplement cost (US\$ 0.17 for kg/supplement). ${ }^{5}$ Operational costs are US\$ 8.08 for months for each animal (US\$ 4.04 for labor and US $\$ 4.04$ for rent pasture). ${ }^{6}$ Daily Cost $=$ Nutrition + Operational. ${ }^{7}$ For the calculated price with ground corn based on the grinding machine, with a 7 horse power motor, price value of US\$ 673.85 , consumption of $5.59 \mathrm{~kW} / \mathrm{h}$, flow rates for coarse ground corn $(2,882 \mu \mathrm{m})$, medium ground corn $(1,011 \mu \mathrm{m})$, and fine ground corn $(0,621 \mu \mathrm{m})$ of $1,300,1,000$ and $700 \mathrm{~kg} / \mathrm{h}$, respectively. The price of power consumption, taking into account the mean year in Brazil, had a value of US\$ 0.25/kW. ${ }^{8}$ Weaning bulls cost US $\$ 1.34 / \mathrm{kg}$ of BW. ${ }^{9}$ Interest is $5 \%$ a year. ${ }^{10}$ Total Cost $=$ Total nutrition Cost + Total Operational Cost + Grinding, Weaning Bull buy + Interest. ${ }^{11}$ Nutritional cost/production kg. ${ }^{12}$ Total cost kg produced $=$ period cost/production $\mathrm{kg} .{ }^{13}$ Gross Revenue is sale of animal final period (US\$ $1.34 / \mathrm{kg}$ of BW).${ }^{14}$ Net Revenue $=$ Gross Revenue - Total Cost. ${ }^{15}$ Profit $=($ Net Revenue/Gross Revenue $) \star 100$. ${ }^{16}$ Profitability $=$ Profit $/ 3$ moths. 